ate far more slowly: you consume the same amount of energy during that time: you store it up in the train and you now waste it all at the same rate you put it in before, by braking. Thus you have the same average speed maintained, and the same time consumed: but in one case a very rapid acceleration and coasting to the other station: whereas, in the other case the acceleration is very slow and a sudden braking. But of course in practice that may not fit the conditions. It may require too high speed to be maintained or too high an acceleration, more than can be obtained, so that the next best thing we can do is to get as high speed as is permissible at first, run along and come out at the end so that we have to use as little braking as possible: possibly putting on power again in case the speed fails to be maintained as is needed. Of course, the system must be flexible, and we do not ever hope to meet the theoretical conditions, but we must approach them as near as practice will allow. The point is, to determine what is the theoretical condition, and then see how nearly we can come to it in actual practice.

The President :- It seems to me that the problem from a mechanical point of view is an extremely simple one. The fact that the author considers paradoxical, is simply this; that if you had an infinitely rapid rate of acceleration to a given speed and then an infinite rate of retardation as suggested by Mr. Steinmetz, and leaving out the question of stops, you would get the most economical condition, and hence the kinetic energy put into the train would be a minimum.

The following paper on "The Cost of Steam Power, by Mr. H. A. Foster," was read at the morning session, July 28 th, by the Secretary, in the absence of the author: 


\section{THE COST OF STEAM POWER.}

BY HORATIO A. FOSTER.

In this age of electricity, when so much is being done in the way of developing its applications, and especially in its application to the transmission and distribution of power, perhaps no one item causes so much controversy as the cost of steam and other familiar forms of power. It seems to have been taken for granted for years that anyone and everyone knows the cost of developing power by steam, and in almost all cases when a person stating such costs is pinned down to facts, it has been found that he is either guessing, or quoting those he supposes are authorities. It is to be presumed that statements of actual tests for cost might have been published, but the writer has in a somewhat extended search run across but one such statement that might be considered reliable, and that was a test for something under 100 days, and that practically confined to the warm season of the year and not therefore of the greatest value.

Other estimates have been made from extended experience and carefully revised theory, and in fact little can be added to tables published during the past few years by some of our most eminent and best qualified engineers, in the way of carefully prepared estimates of what should perhaps be called the average cost of producing steam power under various conditions as to amount of power and the type of machinery employed.

It must be said, though, that almost all these estimates have been made for powers of large size and where little variation of load takes place, and, while such estimates are of great value for use in discussion of the subjects, the writer has found them somewhat unsafe to use unless their results are applied in con- 
nection with extended experience, for, while the results considered as averages are probably correct for ordinary conditions, they cannot of course be expected to include extraordinary conditions, and the results of this investigation seem to show that individual cases vary so much that it is not fair, and may be misleading to state average costs.

It seems a pity that the cost of power is most often quoted for one horse-power for one year, and so freely assumed that there is an average cost of power on which one can base estimates in the cost of manufacture; for the writer will endeavor to show, as this paper progresses, as others have done, first, that any general statement of the cost of power per horse-power per annum is incorrect, for the reason that such a statement does not ordinarily take into account the number of hours run per diem, or the number of days per year, and even in that class of plants supposed to run, say 308 days per annum, it is seldom one can be found that runs a full year, and no two rum the same length of time; and second, that no such statement of an average cost of power is of any value whatever, unless it be for plants employed in similar work, and under exactly similar conditions, and even then the amount of power developed is such a factor for varying the unit cost that it is in the opinion of the writer quite fair to say that there is no average unit cost for steam power, that is safe for general application, and it is thought that a somewhat careful study of the tables and computations accompanying this paper will help to a clearer understanding of the reasons therefor.

Although in the great majority of instances office accounts are so kept as to give no real basis upon which to compute the cost of power, and in most off-hand estimates, the rated capacity and not the average power developed has been used as a divisor, there can be no doubt that in some of the older industries, say in the great flour mills and the large eastern cotton factories, where prices of manufactured goods have been tending downwardly for so many years, and very close accounts of unit cost have necessarily been kept, and, as in all other departments the power has been very carefully looked after, that in such cases it is very likely that careful comparisons will show the cost of power to be more or less uniform when used under similar conditions, but reference to the tables will show this to be more widely at variance than is commonly thought. 
It will be the endeavor of the writer to show by tabulated data as far as possible, the condition of the plants tested, without going any more into detail than seems necessary for a clear understanding.

In order that the value of the results may be determined, it is necessary to give some description of the methods pursued in obtaining them, and, as they were as far as possible the same throughout, a general description will do for all except the special cases.

In order that the greatest value might be obtained, it has always been the opinion of the writer that no results for a period short of twelve consecutive months should be used, and in all but one case which was for eleven months, a year has been taken as the smallest unit of time.

In a general way, the unit of time having been settled, where possible a unit of output was selected, after a careful and somewhat extended study of the special business in all its conditions, on which averages could be constructed and which could be turned into horse-power after determining its rate.

Indicator tests were always made both for determining the rates of power and the ratio of power to the unit of output: for instance, in a flour mill it is only necessary to apply indicators to the engine cylinder for a certain period of time, not less than 24 hours, and to count the actual output in barrels, to determine a fairly accurate ratio of horse-power per barrel of production, after which it is a simple matter to determine the average for a year from a total production and the actual time during which the mill was running and the output recorded; or in an are lighting station, if an indicator test is made of the engine for the entire time per day, during which lamps are burned, and the number of lamps running during the same period be recorded, then also it is easy to determine the ratio of power to lamps, whence by computation from the records kept of the number of lamps burning and the time in hours during which they were lighted for a year, the lights can be reduced to horse-power, and if accurate and well classified records of expenditure are kept, the annual and hourly cost of power is determinable to a close degree of accuracy. Of course, wide variations in the amount of power used will often change the ratio, but care has been taken in these tests, not to base them on periods of changing power consumption, and it is therefore 
thought that the results are within the ordinary limits of accuracy.

.For the sake of uniformity, as well as to reduce the items of account to as emall a number as was considered consistent with clear understanding, a list of cost accounts was determined on, that in most ways agrees with work previously done in this line, and which it was thought could be most easily met by the most ordinary bookkeeping.

The list is as follows:

Operating Expenses.

Fuel.

Wages.

Supplies.

Repairs.

Water.

Incidentals, including lighting and removal of ashes. Fixed Charges.

Interest on cost of plant.

Depreciation on value of plant.

Insurance.

Taxes.

In considering the value to be given to each item, many things had to be discussed in order that proper separation of expenditure due to items other than for power could be made, as for instance the item of fuel; in many cases buildings have had to be heated, either by exhaust or live steam; steam has been used for hot tables, as in the case of newspaper offices, and for dry rooms for lumber etc. as is the case of a furniture factory. In all such cases the study of the plant, consultation with the engineer in charge and the management, coupled with the experience of the writer has ensured the determination of an amount satisfactory to all concerned as being the nearest correct obtainable under the ordinary conditions of practice.

In the item coming under the head of fixed charges, a somewhat different treatment obtained, as so little attention is given these items by the ordinary business management that in most instances not only the value of the plant, but the items going to make up the fixed charges had to be determined by the writer from his experience, together with such information as could be gotten from the people in charge. While insurance and taxes were of course determinable from the books, interest was rated in almost all cases at 5 per cent., and depreciation at rates varying 
from $2 \frac{1}{2}$ to 10 per cent. for building, and 5 to 15 per cent. on steam plant, all according to type of material in use, its condition, the manner in which it was handled, etc. In but few cases were either of these items considered in the estimates of cost by the owners. It must be remembered in this connection, that fixed charges go on all the time, 24 hours per day for 365 days, and that the unit cost is the same if computed by the year, but does not have the same relative value when computed by the number of hours the power was actually in use. In passing, it may be well to say that the number of firms in good business standing that are entirely at sea regarding the actual cost or present value of power plant is to say the least astonishing.

One item taken into consideration in all the tests, and one seldom considered at all in the ordinary statements of the cost of power, is the value of the building or part of the building devoted to the use of the power plant. In some few cases buildings were set apart for this purpose, and where the value was known it was of course easy to fill out the item; but in cases where the power plant was in the same building with the other portions of the plant, it became necessary to set off the value from the rest, and this was most often done by determining the renting value of the room used, which can usually be done with small chance of error, and then to capitalize the rent as the value of that part of the building devoted to power purposes.

In one item used in these tests, the writer apparently differs from most other estimators of the cost of power, and that is in the use of the indicated horse-power rather than brake horsepower for the divisor, and his reasons for using it are as follows: viz:-Indicated horse-power can nearly always be determined to a degree of accuracy only limited by the usual errors of instruments and their users, generally conceded to be small; while brake tests can seldom be made in practice, and the net power is therefore most often determined by assuming a certain percentage of engine and shafting efficiency which under general conditions is quite incapable of proof, and the errors of which must be added to those of the indicator test. The writer therefore prefers to eliminate this chance for error, and should any one desire to change the figures here displayed to brake horse-power, it is only necessary to make the single computation due to any engine effieiency that he may wish to assume.

Referring now to plants tested, those on which reports were 
made were not selected in order to show the very considerable variation in results that are given, but for availability and for variety of types and of business.

The plants on which tests were made for unit cost of power were :

Two Electric Lighting Stations.

One Grain Elevator.

Three Water Works Pumping Stations.

Two Flouring Mills.

Six Cotton Mills.

Four Newspaper and Printing Offices.

One Department Store.

One Furniture Manufactory.

One Bakery.

One Glazed and Fancy Paper Manufacturing Company.

The criticism may be offered that not enough plants were tested in any one business to determine an average cost of power in that business, and a careful inspection of the following tables will show that comparisons of cost of power between unlike types of business are of little value, and if still further comparisons be made, it will be found that conditions vary so much in the same type of business as to show that any statement of an average cost of power even there is quite misleading and that therefore tests of even a single plant of any of the different classes of business is of value only so far as it determines the cost for that plant alone, and demonstrates the fact of which the writer has become thoroughly convinced, that each plant must be tested as if it were the only one of the type in existence.

Coming now to tables, table I for easy reference, gives the number of the plant, the number and type of boilers, with all their dimensions, and the nature and cost of fuel used.

Table II is a continuation of table $\mathrm{I}$, stating the number and type of engines used with all cylinder dimensions and rated power: the total plant value with the value per rated horsepower; the number of men employed with their average wages, and remarks on the use of steam for purposes other than for power, when taken from the boilers supplying the engines.

The above tables, perhaps, need little explanation, as all items are placed in columns so that results shown in other tables can easily be traced back and possible reasons for the conditions be shown in the plant equipment or the way it may be handled. 


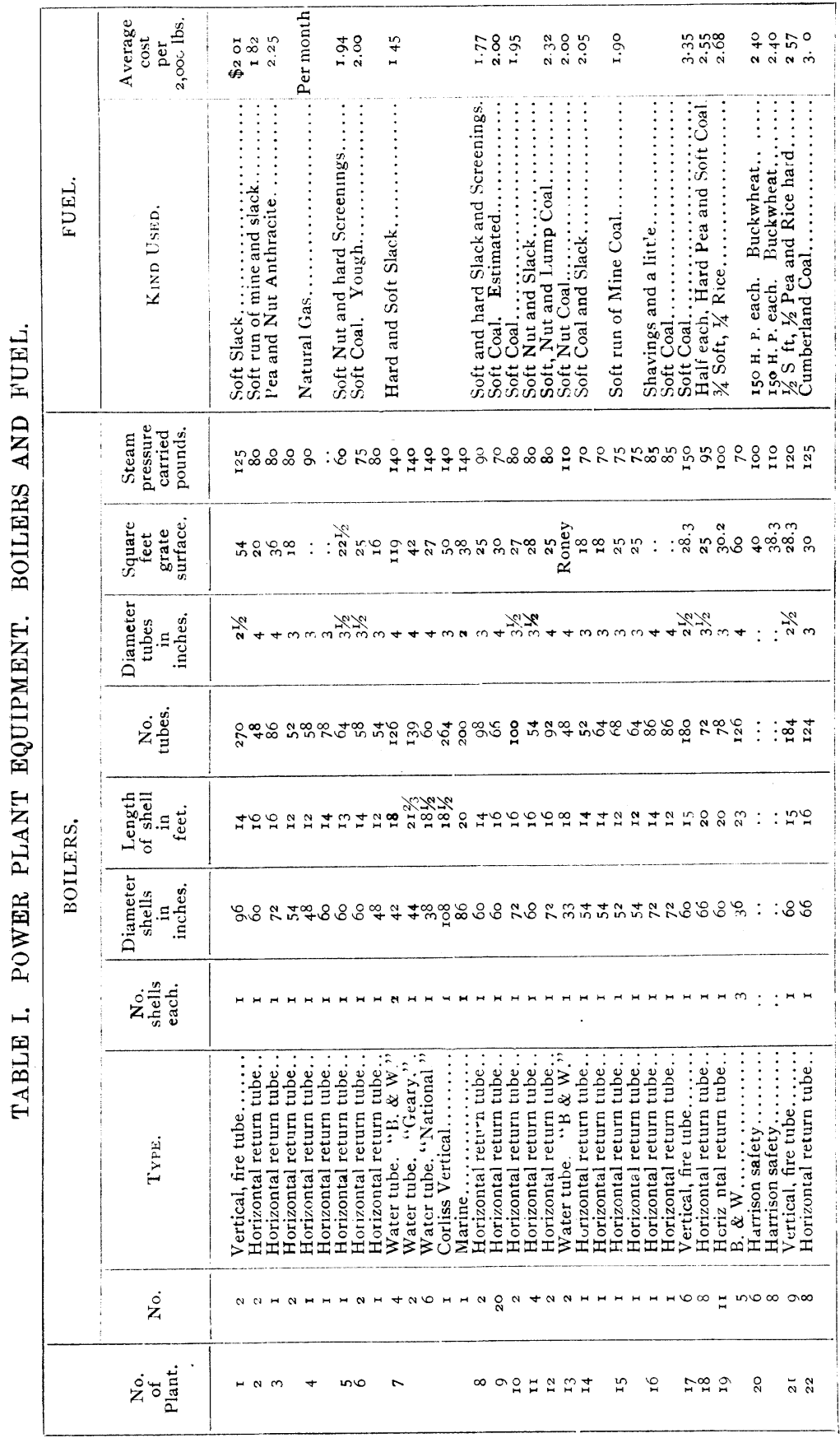


It will be seen that in rated capacity the plants vary from 40 horse-power to 2,500 and in value per rated horse-power from $\$ 23$ to $\$ 89$ in steam power plants, or as high as $\$ 368$ in water works pumping stations.

While the type of boiler used leans largely to the plain, oldfashioned return tubular, with the exception of the cotton mills, the types of engines are almost as varied as the number of plants.

In fuel, soft coal or slack of soft coal largely predominates, and a considerable use of mixtures of the latter with dust from the yards and hard coal slack will also be noticed, which is largely due to efforts to reduce the smoke nuisance.

In table III, under the general heads of "out-put," "operating expense" and "fixed charges," are shown all the items in detail. for each plant, going to make up the total annual cost of power, and in table III a, will be found the items making up the cost per horse-power per hour.

The first column in table III, under "output," shows the average power developed for one year covering the number of days and hours per day shown in the third and fourth columns; and column 2 shows the percentage of the total rated capacity that the average power actually developed bears to the rated horsepower of engines, as shown in table II. The time in hours per day shown in column 4 , is not in all cases the actual average per day for the year, but the regular time on which the plant was run during the year under consideration, therefore multiplying the figures in this column by the days actually run will not in all cases give as a result the total hours per annum shown in the sixth column, which are the actual hours run in each case.

In table III, under the headings of "operating expense," "fixed charges," and "cost per horse-power," the figures are the costs per annum for each item, while table III $_{\mathbf{A}}$, gives the cost per horse-power per hour obtained by dividing the annual cost of each item by the number of hours run as shown in the sixth column.

In tables II, $\mathrm{v}$ and $\mathrm{vI}$, the results from the different plants have been separated and classified according to the hours per diem during which they are run, making the broad distinction of 20 to 24 hour runs and 9 to 12 hour power, there are however two plants that, owing to wide difference of running time could not be brought under these headings, and they have therefore been placed by themselves in table vi. 


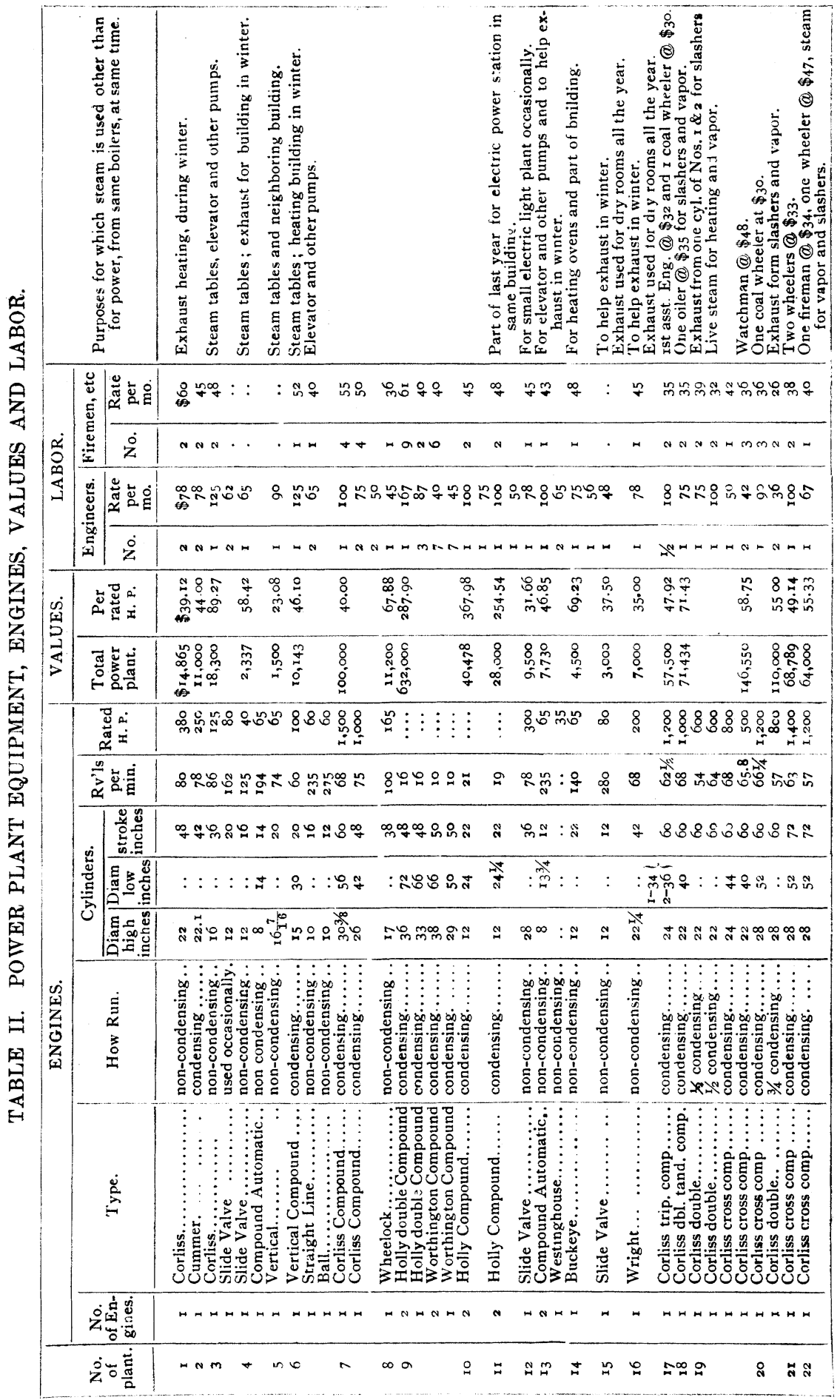




\begin{tabular}{|c|c|c|c|}
\hline \multirow{20}{*}{ 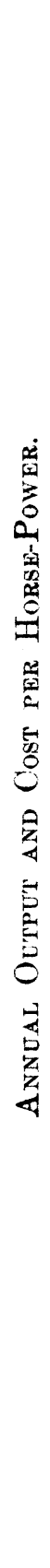 } & & 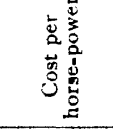 & 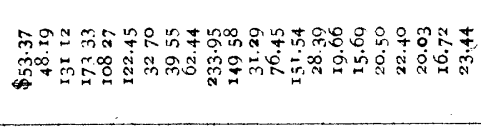 \\
\hline & \multirow{5}{*}{ 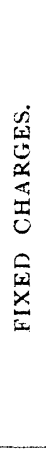 } & $\stackrel{\dot{\pi}}{\stackrel{5}{0}}$ & 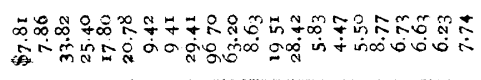 \\
\hline & & 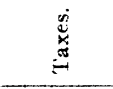 & 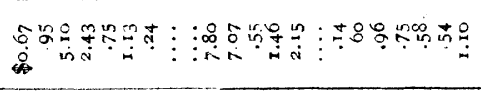 \\
\hline & & 妾密 & 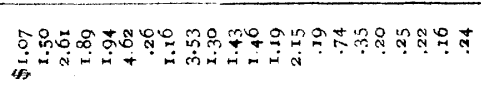 \\
\hline & & ن. & 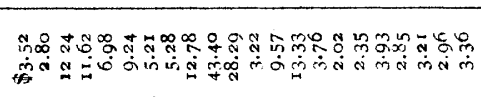 \\
\hline & & 晜它 & 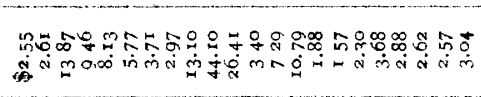 \\
\hline & \multirow{7}{*}{ 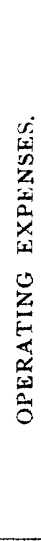 } & $\sum_{i=1}^{i}$ & 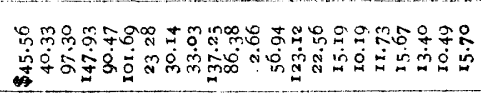 \\
\hline & & 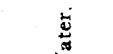 & 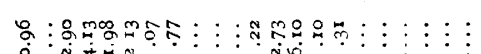 \\
\hline & & 3 & $\Leftrightarrow$ \\
\hline & & 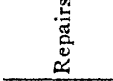 & 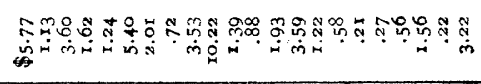 \\
\hline & & 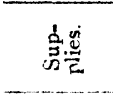 & 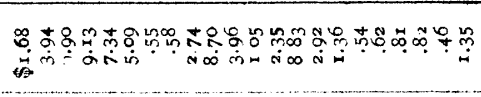 \\
\hline & & $\underset{:}{:}$ & 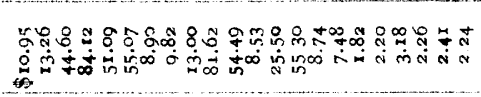 \\
\hline & & $\underset{\Phi}{\dot{\Phi}}$ & 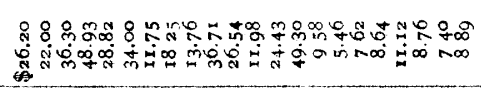 \\
\hline & \multirow{6}{*}{$\begin{array}{l}5 \\
5 \\
0 \\
0\end{array}$} & 棓岁鸹 & 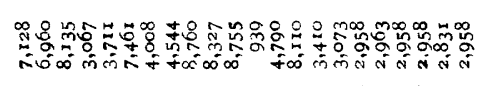 \\
\hline & & \multirow{2}{*}{ 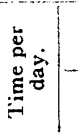 } & 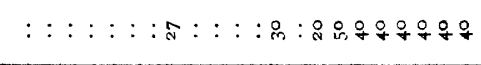 \\
\hline & & & 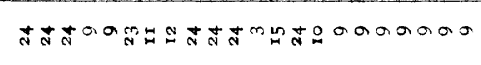 \\
\hline & & 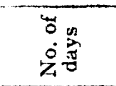 & 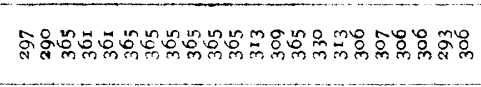 \\
\hline & & 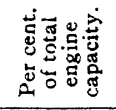 & 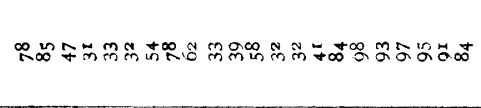 \\
\hline & & 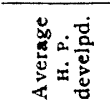 & 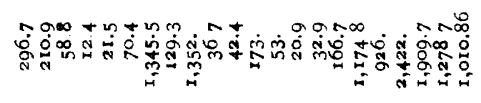 \\
\hline & \multicolumn{2}{|r|}{ 㝋泀 } & 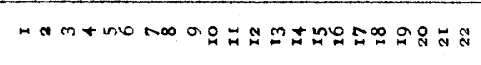 \\
\hline
\end{tabular}




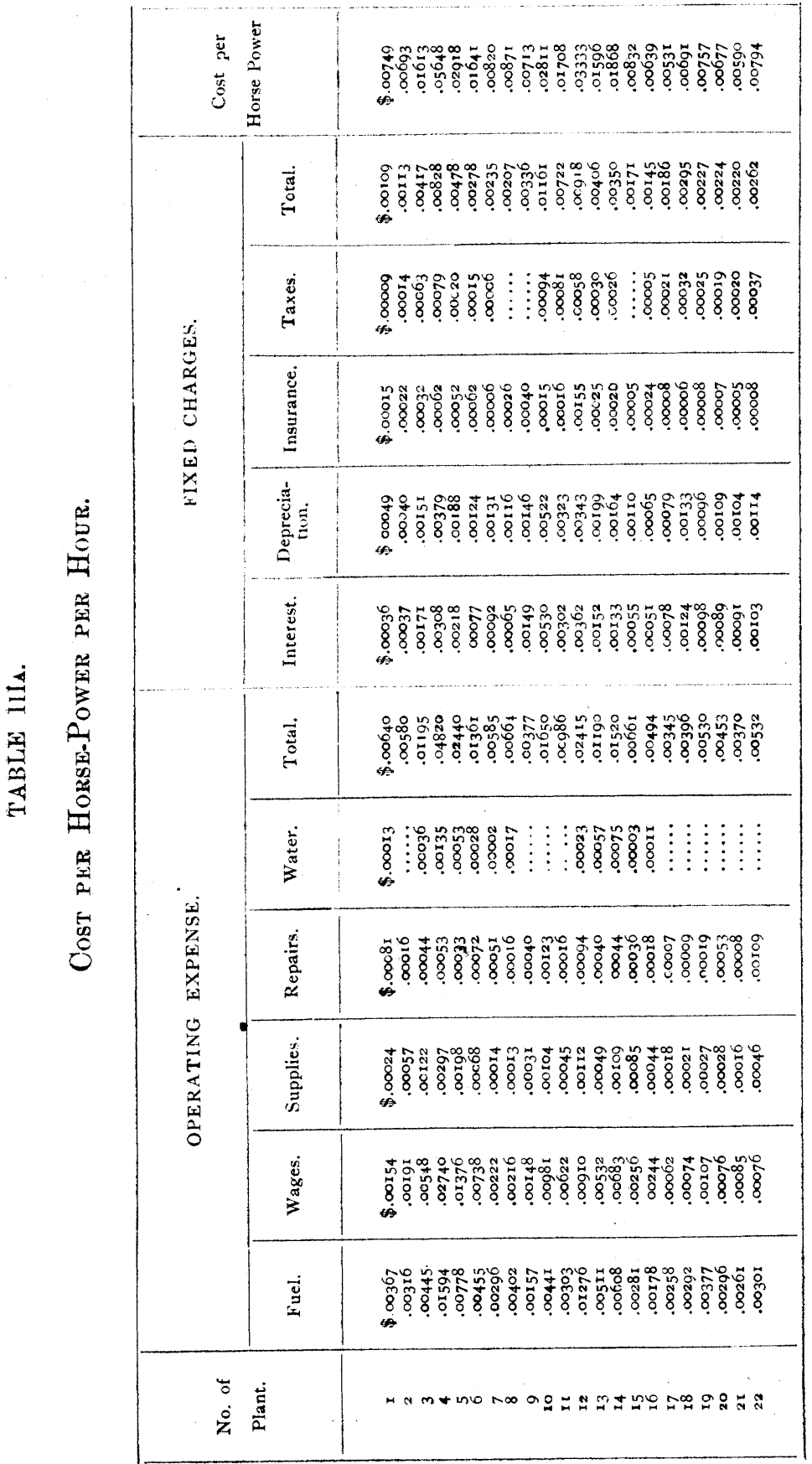


In considering the plants under these general divisions, it must still be borne in mind that while they are classed under the same heading in hours per diem, they are by no means all run the same number of days per year, and therefore the total hours per annum during which the plant was run becomes the only correct basis on which to compute the cost for comparison.

In the above tables the unit costs per year, per day and per hour, have been computed and placed in parallel columns, the first and last being from table III, while the cost per day is deduced from the actual number of days run, divided into the cost per annum.

TABLE IV.

Unit Costs for 20 to 24 Hour Power.

\begin{tabular}{|c|c|c|c|c|}
\hline \multirow{2}{*}{$\begin{array}{c}\text { Number } \\
\text { of } \\
\text { Plant. }\end{array}$} & \multirow{2}{*}{$\begin{array}{c}\text { Average } \\
\text { Horse-Power } \\
\text { D. veloped. }\end{array}$} & \multicolumn{3}{|c|}{ COST S. } \\
\hline & & $\begin{array}{c}\text { Per } \\
\text { Horse-Power, } \\
\text { Year. }\end{array}$ & $\begin{array}{c}\text { Per } \\
\text { Horse-Power, } \\
\text { Day. }\end{array}$ & $\begin{array}{c}\text { Per } \\
\text { Horse-Power, } \\
\text { Hour. }\end{array}$ \\
\hline $\begin{array}{r}1 \\
2 \\
3 \\
6 \\
9 \\
10 \\
11 \\
14\end{array}$ & $\begin{array}{r}296.7 \\
210.9 \\
58.8 \\
70.4 \\
\times 352.0 \\
367 \\
42.4 \\
20.9\end{array}$ & $\begin{array}{r}\$ 53.37 \\
48.13 \\
131.12 \\
122.45 \\
62.44 \\
233.95 \\
149.58 \\
151.54\end{array}$ & $\begin{array}{r}\$ .1797 \\
.1662 \\
.3592 \\
.3355 \\
.1711 \\
.6409 \\
.4098 \\
.4152\end{array}$ & $\begin{array}{r}\$ .00749 \\
.00693 \\
.01613 \\
.01641 \\
.00713 \\
.02811 \\
.01708 \\
.01868\end{array}$ \\
\hline
\end{tabular}

TABLE $V$.

Untr Costs for 9 to 12 Hour Power.

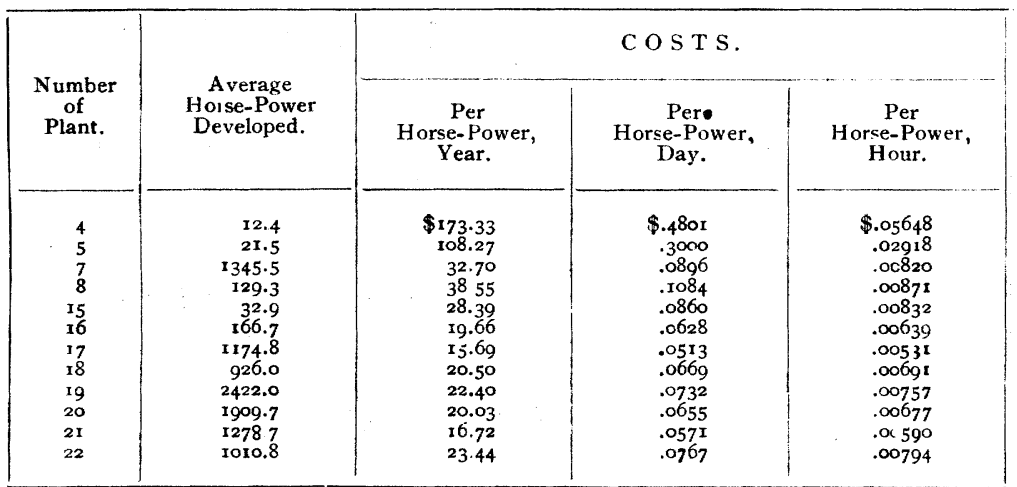

In tables vII, viII and XI, and under the same general headings as to hours run per diem, as in tables IV, $v$ and vi, a comparison is made of the amount of power used as compared with 
TABLE VI.

Unit Coste for 3 Hour Power and for $15 \frac{1}{2}$ Hour Power.

\begin{tabular}{|c|c|c|c|c|c|}
\hline $\begin{array}{c}\text { Hours } \\
\text { Run. }\end{array}$ & $\begin{array}{c}\text { Number } \\
\text { of } \\
\text { Plant. }\end{array}$ & $\begin{array}{c}\text { Average } \\
\text { Horse-Power } \\
\text { Developed. }\end{array}$ & $\begin{array}{c}\text { C O S T S. } \\
\text { Horse-Power, } \\
\text { Year. }\end{array}$ & $\begin{array}{c}\text { Per } \\
\text { Horse-Power, } \\
\text { Day. }\end{array}$ & $\begin{array}{c}\text { Per } \\
\text { Horse-Power, } \\
\text { Hour. }\end{array}$ \\
\hline 3 & 12 & 173 & $\$ 31.29$ & $\$ .1000$ & $\$ .03333$ \\
$155 / 2$ & $1_{3}$ & 53 & 76.45 & .2473 & .01596 \\
\hline
\end{tabular}

the actual rated capacity and under the items of expense are shown the total operating expense per hour, the total fixed charges per hour and in the last two columns the percentage each is of the total cost.

TABLE VII.

Comparizon of Puwer and Expenses. 20 To 24 Hours.

\begin{tabular}{|c|c|c|c|c|c|c|c|}
\hline \multirow{2}{*}{$\begin{array}{c}\text { No. } \\
\text { of } \\
\text { Plant. }\end{array}$} & \multirow{2}{*}{$\begin{array}{c}\text { Rated } \\
\text { Capacity, } \\
\text { H. P. }\end{array}$} & \multirow{2}{*}{$\begin{array}{c}\text { A verage } \\
\text { Used } \\
\text { H. } 1 .\end{array}$} & \multirow{2}{*}{$\begin{array}{l}\text { Per cent. } \\
\text { Used } \\
\text { of } \\
\text { Capacity. }\end{array}$} & \multicolumn{4}{|c|}{ Expense per H. P. HoUt. } \\
\hline & & & & Operating. & Fixed. & $\begin{array}{l}\text { Per cent. } \\
\text { Operdting } \\
\text { of lolal }\end{array}$ & $\begin{array}{l}\text { Per cent, } \\
\text { Fixed of } \\
\text { 'lotal. }\end{array}$ \\
\hline I & 380 & 296.7 & 78 & $\$ .00640$ & $\$ .00109$ & 8 & $I_{5}$ \\
\hline 2 & 250. & 210.9 & 85 & .00580 & .00113 & 84 & 16 \\
\hline 3 & 205 & 58.8 & 47 & $.0: 195$ & .00417 & 74 & 26 \\
\hline 6 & 220 & 70.4 & $3^{+1}$ & .01361 & $\infty=78$ & 83 & 17 \\
\hline 9 & 2195 & 1352.0 & 62 & .00377 & .00336 & 53 & 47 \\
\hline Io & IIO & 36.7 & 33 & .01650 & $.015 \mathrm{r}$ & 58 & 42 \\
\hline II & IIO & 424 & 39 & .00986 & .00722 & 57 & 43 \\
\hline$I_{4}$ & 65 & 20.9 & $3^{2}$ & .01520 & $.0035^{\circ}$ & $8 r$ & ig \\
\hline
\end{tabular}

'TABLE VIII.

Comparison of Power and Expenses.

9 Hours to 12 Hours.

\begin{tabular}{|c|c|c|c|c|c|c|c|}
\hline \multirow{2}{*}{$\begin{array}{c}\text { No. } \\
\text { of } \\
\text { Plant. }\end{array}$} & \multirow{2}{*}{$\begin{array}{c}\text { Rated } \\
\text { Capacity, } \\
\text { H. P. }\end{array}$} & \multirow{2}{*}{$\begin{array}{c}\text { Average } \\
\text { Used } \\
\text { H. P. }\end{array}$} & \multirow{2}{*}{$\begin{array}{l}\text { Per cent } \\
\text { Used } \\
\text { of } \\
\text { Capacity. }\end{array}$} & \multicolumn{4}{|c|}{ EXUENSE PER H. P. HOUR. } \\
\hline & & & & Operating. & Fixed. & $\begin{array}{l}\text { Per cent. } \\
\text { Operating } \\
\text { of Total. }\end{array}$ & $\begin{array}{c}\text { Per cent. } \\
\text { Fixed of } \\
\text { Total. }\end{array}$ \\
\hline 4 & 105 & 12.4 & $3^{x}$ & $\$ .04820$ & $\$ .00828$ & 86 & I4 \\
\hline 5 & 65 & $2 \mathrm{I} .5$ & 33 & .02440 & .00478 & 84 & 16 \\
\hline 7 & 2500 & I 345.5 & 54 & .00585 & .00235 & 71 & 29 \\
\hline 8 & 165 & 128.3 & 78 & .00664 & .00207 & $7^{6}$ & 24 \\
\hline 15 & 80 & 32.9 & 41 & $.0066 \mathrm{r}$ & .00171 & 79 & $2 \pi$ \\
\hline 16 & 200 & I66.7 & 84 & .00494 & .00145 & 77 & 23 \\
\hline$I_{7}$ & 1200 & 11748 & 98 & .00345 & .00186 & 65 & 35 \\
\hline I8 & 1000 & 926.0 & 93 & .00396 & .00295 & 57 & 43 \\
\hline I9 & 2500 & 2422.0 & 97 & .00530 & .00227 & $7 \mathrm{I}$ & 29 \\
\hline 20 & 2000 & rgog.7 & 95 & .00453 & .00224 & 67 & 33 \\
\hline 21 & 1400 & 1278.7 & $9 \mathrm{I}$ & $.0037^{\circ}$ & .00220 & 63 & 37 \\
\hline 22 & 1200 & 1010.8 & 84 & $.0053^{2}$ & .00262 & 67 & 33 \\
\hline
\end{tabular}


TABLE IX.

Comparison of Power and Expenses.

3 Hours and $15 \frac{1}{2}$ Hours.

\begin{tabular}{|c|c|c|c|c|c|c|c|c|}
\hline & & & & & \multicolumn{4}{|c|}{ EXPENSES PER H. P. HoUR. } \\
\hline $\begin{array}{c}\text { No. } \\
\text { of } \\
\text { Plant. }\end{array}$ & $\begin{array}{c}\text { Hours } \\
\text { Run. }\end{array}$ & $\begin{array}{c}\text { Rated } \\
\text { Capacity } \\
\text { H. P. }\end{array}$ & $\begin{array}{l}\text { A verage } \\
\text { Used } \\
\text { H. P. }\end{array}$ & $\begin{array}{l}\text { Per cent. } \\
\text { Used of } \\
\text { Capacity. }\end{array}$ & Operating. & Fixed. & $\begin{array}{l}\text { Per cent. } \\
\text { Operating } \\
\text { of Total. }\end{array}$ & $\begin{array}{c}\text { Percent. } \\
\text { Fixed } \\
\text { of Total. }\end{array}$ \\
\hline 12 & 3 & 300 & 173 & $5^{8}$ & .02415 & .00918 & $7^{2}$ & 28 \\
\hline$r_{3}$ & $J_{5} 1 / 2$ & 165 & 53 & 32 & .01190 & .00406 & 75 & 25 \\
\hline
\end{tabular}

Referring back to table iv and taking up the plants in order, it will be well to discuss each one, in-so-far as may be necessary to explain why it differs in cost from another similar plant of which test is also given.

Commeneing then with plants No. 1 and 2, being used for similar purposes, the first being somewhat larger in capacity than the second.

The first has a Corliss, non-condensing engine and boilers of a very efficient vertical type, while the second has old and comparatively inefficient return tubular boilers, but a good type of engine, running condensing, which accounts for the cost being somewhat less than for plant number one.

It may be said that during the test the first of these plants was found to be using a great deal more coal when the night fireman was on duty, than the day tireman used in the same length of time, and for an average of two horse-power in excess over that developed during the night. Since the test, this has been remedied and it is said that the plant is now running at a very considerable saving over its former condition. The waste of coal as mentioned above, is one of the items that cannot be included in any theoretical computation, but is too common in practice.

Plants 3 and 6 , both run similar types of business, the first getting its power from a fine simple Corliss engine kept in the best of order, while the other uses one very old type of engine running compound condensing, and two small high speed engines, running at high pressure. Both plants are well kept and the final results in costs per horse-power per hour is seen to vary but .0003 .

The next three cases 9, 10, 11 are three pumping stations 
under city control, and while the total cost seems high, it must be remembered that fixed charges account for a good part of the entire expense, and in making comparisons between plants of this kind and other power, it will be more fair to compare operating expenses only, and in that case the showing while high is not so much higher than for other plants of a similar capacity as to be startling.

The last case in this division, No. 14, was the only one of the nature of business carried on and the only detail given will be to say that it had a Buckeye engine, kept in the best of order.

Plants Nos. + and 5, in table $\mathrm{v}$, are used in similar business, and in spite of the fact that the first has by far the better plant, the cost is seen to be a great deal higher than in the second case, and mainly for the reason that a larger average output is obtained from the latter plant.

Case No. 7 in the same table is one in which the circumstances were such as to enable the determination of cost with extreme accuracy, the output being uniform and constant and the accounts most accurately kept. The cost is somewhat higher than it might be, owing to rather low ratio of output to capacity, but this has since been remedied and the unit cost materially reduced.

Plant No. S is one that will answer for a type of hundreds of small electric lighting stations in the United States, and the test is only remarkable in the variety of ontput, making it necessary to do a very large amount of calculation in order to arrive at anything like reasonably correct results. Fortunately for the purpose, ampere records had been kept of the incandescent part of the ontput, as well as a clear record of the number of are lamps run, together with the time of running for each night of the year.

By making an indicator test of the engine, and at the same time recording the amperes and volts at the switchboard, it was easy to arrive at the average power for a complete run and thus to estabiish a ratio of steam power to electrical ontput for the entire year, and by means of the ratio converting it into horsepower, an average power for the entire year was determined.

The resulting cost per horse-power is surprisingly low and is due to several things, first, low rate of wages; second, just as little labor as could run the plant, and third, cheap fuel.

A calculation of the cost of the electric output in this plant 
shows it to be not nearly so economical as might with reason be expected from the low cost of steam power, and is due to the low average efficiency of the plant, caused by running for many hours at light loads.

Plant $\mathrm{No}$. 15, is one of that type of plants that uses steam for power purposes, more as an incident of the manufacture than as one of the prime factors in cost.

Steam for drying goods is the chief factor in plants of this kind, and in this case all the exhanst from the engine and in cold weather much live steam is used for drying purposes.

Plant No. 16, like the last one, uses a great proportion of its steam for drying purposes, and an additional factor for low power cost is, that nearly all fuel for day use is the waste wood and shavings from the manufacture. Add to this the fact that the machinist acts as engineer, and the engine is of good size and located in the machine repair shops and it will be seen that most of the factors in the case make a very low cost of power.

Plants Nos. 17 to 22 inclusive, are large cotton mills, in an eastern state. The statement made in the early part of this paper, seems to be borne out that, while it might be thought that mills of this nature using as large units of power as do these, and in a business so near alike for all, would perhaps show a more uniform cost of power, still vary a somewhat larger amount than would be practicable to average.

The eost of the lowest, No. 17 , is $\$ 00531$ per horse-power hour and the highest, No. 22, $\$ 00794$, a difference of nearly 50 per cent increase over the first mentioned plant. To be sure, the first named plant (No. 17) is a new style Corliss, 4 cylinder, triple expansion, condensing engine, while the last (No. 22) is of the cross-compound condensing Corliss type.

Of course, it is readily seen that the extra cost could not be in fuel efficiency, and by reference to table III, it will be seen that the difference is in "supplies" and "repairs" to a very large extent, caused by a charge of part of the expense of replacing the whole bank of boilers. This is one of the items of cost that so often happen in steam plants, and the charge is seldom included in figuring the cost of power.

Comparing No. 17 with No. 21, the total cost per hour for the former is $\$ .00531$ and for the latter $\$ .0059$, a difference of $\$ .00059$, or 11 per cent of the first named plant.

Again referring to table II, another perhaps unexpected re- 
sult is found, $i$. e. the fuel cost for the triple expansion engine is higher than in the other (No. 21), which is a Corliss crosscompound condensing engine.

As both plants use Manning boilers that are presumably of like efficiency, a reference to table I shows that the coal used in No. 17 cost $\$ 3.35$ per ton, while the mixture used in No. 21 , cost but $\$ 2.57$ and the difference in quantity used that may have been due to higher engine economy, seems not to have made up for the difference in price.

Taking up the wages cost for these six plants, an examination of tahles III and III a, shows a very considerable variation in that item, due to a number of different factors: for instance, No. 22 has but one engineer, with not even an oiler, but the number of firemen used brings up the cost to a trifle more than on No. 17, where the one engineer divides his time equally between the plant examined and another one, and therefore equally divides the cost, an oiler looking directly after the care of the engine; and the divisor (amount of power developed) is greater in the first case, thus materially reducing the unit cost. The labor cost in steam power can be made one of the greatest variables in it and when it is found to be a fact that one engineer at say $\$ 3.00$ per day, can and does successfully run an engine developing over a thousand horse-power, and yet no less cost than this is required for running a plant of say 200 or even 100 horse-power, it is readily seen that the unit cost differs materially in the two cases and will vary proportionally between the two limits. Of course this is not advanced as new in theory but the writer wishes to call rather closer attention to the point than seems to have been given it in the past.

In table vi, the first plant No. 12, is a large grain elevator in which power is used spasmodically and averages but 3 hours out of the 24 the year round. This power varies in amount to a great extent, running at times as low as 43 horse-power and again with the "marine leg" on, and other "lofters" as high as 250 horse-power may be in use for a short time. The average 173 horse-power is somewhat higher than might be expected with the entire disuse of the marine leg in winter, and only the inside legs going during that time, but it checks well with all the tests made on the plant.

Plant No. 13 is run for $15 \frac{1}{2}$ hours every working day of the year and in spite of the fact that the engine and dynamo plant 
is in duplicate, the cost per horse-power is quite low; this is mainly due to extremely good management and careful accounting. Power is mainly used for running electric lights and one or two small motors. Steam is used for power and for an elevator and other pumps. An accurate record is kept of the weight of coal used each day, and the reading of the ampere and voltmeters is registered all day long at hourly intervals, thus enabling a quite accurate estimate to be made of the average power, by determining the ratio of eylinder power to ampere readings.

While the above 22 plants are the only ones on which tests available for this paper were carried out, many others were examined during the time, and while it may be said that in most plants fairly accurate tests may be made, some are found in which it is next to impossible to arrive at anything like accurate results.

Until one makes a business of examining power plauts with an idea of learning the unit cost of power, it is impossible to judge adequately of the varying conditions obtaining and therefore of the fact that any possible statement of an average cost is misleading.

It has been the writer's experience that one of the greatest factors for varying the cost of steam power in a given plant is to be found in the fire room.

In but few plants is this part of the expense found to receive the attention it should have to obtain the best results; and as a whole, the men employed at the work of firing are of a class that seldom runs to brains, and unless pushed to it by the management, the engineer is prone to exercise only a nominal supervision over the department. When a fireman on one shift can use nearly twice as much coal doing the same work as the fireman on the other shift as was found in one case, it is time the engineer was disposed of or new methods arranged.

In plants developing a low amount of power, say less than 100 horse-power, as a large majority of them do, the labor item due to varying conditions of the business, becomes a very important factor, and one in which great saving can be made by re-arrangement of power supply.

In order to make this paper of greater value, the writer has thought it well to add the results of estimates by other investigators and, as coal is the only item that varies to a great extent 
in unit price, it has been thought best to bring that item to the same price per ton, and, as the ton used in the neighborhood where most of the tests were made is 2,000 pounds, all weights and prices have been reduced to a cost of $\$ 3.00$ per 2,000 pounds, delivered.

Tables $x$ to $x$ viI inclusive, are the results of the tests by the writer, classified by types of plant, and reduced to coal at $\$ 3.00$ per 2,000 pounds. These tables show the number of the plant as given in the previous tables, the hours run per diem, the average power developed, operating, fixed and total expense per hour per horse-power.

Table $x$, shows the costs for slow speed non-condensing engines, irrespective of the size or number of hours run per diem. Although an arerage is taken of these, it is of course of little value as the costs vary not ouly by reason of the amount of power developed but from the number of hours run per diem, and the variety of each of these conditions is such that each item could as well be placed by itself.

Table XI shows results for high speed antomatic engines, which are also assembled irrespective of time of ruming or power developed and show very uneven costs.

Tables XII and XIII include but one plant each, and are therefore of little use for comparison, excepting as showning the general variation of cost.

TABLE X.

Coat Renuced to $\$ 3.00$ per 2,000 Las.

Slow Speed. Non-Condensing.

\begin{tabular}{|c|c|c|c|c|c|}
\hline \multirow{2}{*}{$\begin{array}{c}\text { Number } \\
\text { of } \\
\text { Plant. }\end{array}$} & \multirow{2}{*}{$\begin{array}{l}\text { Hours } \\
\text { Run. }\end{array}$} & \multirow{2}{*}{$\begin{array}{l}\text { Average } \\
\text { Power. }\end{array}$} & \multicolumn{3}{|c|}{ EX P E N SES. } \\
\hline & & & Operating. & Fixed. & Total. \\
\hline I & 24 & 296.7 & $\$ .00821$ & $\$ .00109$ & $\$ .0093^{\circ}$ \\
\hline 3 & 23 & $5^{8} .8$ & .01343 & .00417 & .01760 \\
\hline 5 & 9 & 21.5 & .02865 & .00478 & .03343 \\
\hline 8 & $\mathrm{I} 2$ & $129 \cdot 3$ & .00692 & .00207 & .00899 \\
\hline 16 & 10 & I66.7 & $.0059 \mathrm{r}$ & .00145 & .00736 \\
\hline 12 & 3 & I73. & .02789 & .00918 & .03707 \\
\hline Averages. & & & $\$ .01517$ & $\$ . \infty 0379$ & $\$ .01896$ \\
\hline
\end{tabular}


TABLE XI.

Coal Reduced to $\$ 3.00$ Per 2,000 Lbs.

High Speed. Automatic Non-Condensing.

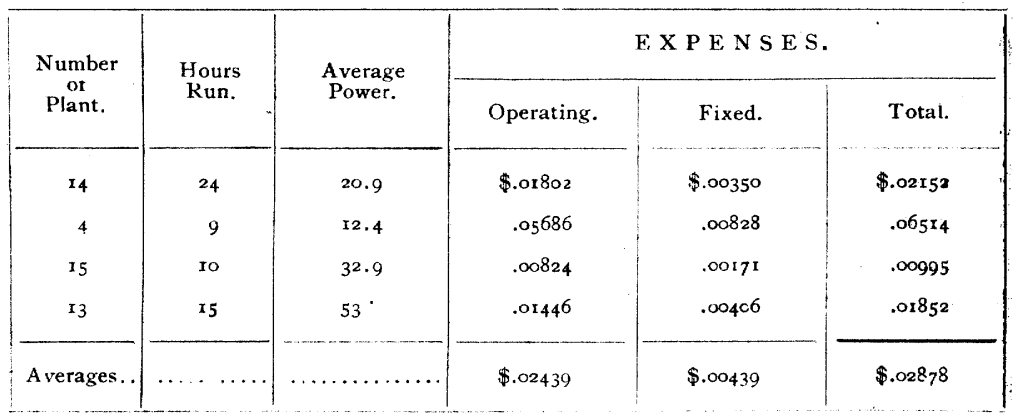

TABLE XII.

Coal Reduced to $\$ 3.00$ per 2,000 Libs.

Slow Speed Condensing.

\begin{tabular}{|c|c|c|c|c|c|}
\hline $\begin{array}{c}\text { Number } \\
\text { of } \\
\text { Plant. }\end{array}$ & $\begin{array}{c}\text { Hours } \\
\text { Run. }\end{array}$ & $\begin{array}{c}\text { Average } \\
\text { Power. }\end{array}$ & \multicolumn{3}{|c|}{ E X P E N S E S . } \\
\cline { 2 - 5 } & Operating. & Fixed. & Total. \\
\hline 2 & 24 & $\$ .00785$ & $\$ .00 r_{3}$ & $\$ .00898$ \\
\hline
\end{tabular}

TABLE XIII.

Coal Redueed to \$3.00 per 2,000 Lbs.

Combined. Compound-Condensing ani) Automatio

Non-Condensing.

\begin{tabular}{|c|c|c|c|c|c|}
\hline $\begin{array}{c}\text { Number } \\
\text { of } \\
\text { Plant. }\end{array}$ & $\begin{array}{c}\text { Hours } \\
\text { Run. }\end{array}$ & $\begin{array}{c}\text { Average } \\
\text { Power. }\end{array}$ & Operating. & Fixed. & Total. \\
\hline 6 & 23 & 70.4 & $\$ .01573$ & $\$ .00273$ & $\$$ or 85 S S S. \\
\hline
\end{tabular}

Table xIv, shows like results for three pumping stations, and one gets a very good idea of the vast difference in unit cost of power when developed is widely varying quantities; the first plant, developing 1,352 horse-power, and the other two less than 50 horse-power each, the difference in cost between the highest and the lowest being as $\$ .007$ is to $\$ .03048$. 
TABLE XIV.

Coal Reduced to $\$ 3.00$ jer 2,000 Lbs.

Pumping Engines, Compound Condensing.

\begin{tabular}{|c|c|c|c|c|c|}
\hline \multirow{2}{*}{$\begin{array}{c}\text { Number } \\
\text { of } \\
\text { Plant. }\end{array}$} & \multirow{2}{*}{$\begin{array}{c}\text { Hours } \\
\text { Run. }\end{array}$} & \multirow{2}{*}{$\begin{array}{l}\text { Average } \\
\text { Power. }\end{array}$} & \multicolumn{3}{|c|}{ E X P E N S S } \\
\hline & & & Operating & Fixed. & Total. \\
\hline 9 & 24 & 1352 & $\$ .00455$ & $\$ .0033^{6}$ & $\$ .0079 \mathrm{x}$ \\
\hline 10 & 24 & 36.7 & .01887 & .01161 & .03048 \\
\hline II & 24 & 42.4 & .01149 & .00722 & .01871 \\
\hline Averages. & $\ldots \ldots$ & $\ldots \ldots \cdot \cdots$ & .01174 & .00739 & .01913 \\
\hline
\end{tabular}

In table $\mathrm{xv}$, is shown the cost for four large plants using slow speed compound condensing engines. This type of plant is perhaps the most common of modern plants in use for large quantities of power, and is one on which perhaps the most and best estimates have been made, and therefore most easily compared with other tables.

TABLE XV.

Coal Reduoed to $\$ 3.00$ per 2,000 Las. Slow Speed Compound Condensing.

\begin{tabular}{|c|c|c|c|c|c|}
\hline \multirow{2}{*}{$\begin{array}{c}\text { Number } \\
\text { of } \\
\text { Plant. }\end{array}$} & \multirow{2}{*}{$\begin{array}{c}\text { Hours } \\
\text { Run. }\end{array}$} & \multirow{2}{*}{$\begin{array}{l}\text { Average } \\
\text { Power. }\end{array}$} & \multicolumn{3}{|c|}{ E X P E N S S. } \\
\hline & & & Operating. & Fixed. & Total \\
\hline 7 & 11 & $\times 345.5$ & $\$ .00901$ & $\$ .00235$ & $\$ .01136$ \\
\hline$x 8$ & 10 & 926.0 & .00447 & .00295 & .00742 \\
\hline 21 & Io & 1278.7 & $.004^{14}$ &.$\infty 0220$ & .00634 \\
\hline 22 & 10 & roto. 8 & .00522 & .00262 & .00784 \\
\hline Averages. & & .. & .0571 & .00253 & .00824 \\
\hline
\end{tabular}

Table xvI, shows the result in one plant using a large triple compound engine of special type, and one of the items tending to low cost in this instance, is that but half the engineer's time is chargeable to this particular plant; another being the low fixed charge owing to very close buying by the management. The cost of power here will be seen to be less than generally estimated. 
TABLE XVI.

Coal. Reweed to \$3.00 per 2,000 Las. Siow Speno Triple Compound Condensing.

\begin{tabular}{|c|c|c|c|c|c|}
\hline $\begin{array}{c}\text { Number } \\
\text { of } \\
\text { Plant. }\end{array}$ & $\begin{array}{c}\text { Hours } \\
\text { Run. }\end{array}$ & $\begin{array}{c}\text { Averaxe } \\
\text { Power. }\end{array}$ & \multicolumn{3}{|c|}{ EXXENSES. } \\
\hline 17 & 10 & 1174.8 & Operating. & Fixed. & Total. \\
\hline 1700318 & $\$ .00186$ & $\$ .00504$ \\
\hline
\end{tabular}

Table xvir, shows the results in two mixed plants of large size, both cotton mills. In both cases about half the plant consists of the best type of compound condensing engines, while the rernainder is made up of the old-fashioned double Corliss part condensing type, the exhaust from one end of each cylinder being generally nsed for purposes of heating about the mills. In passing, it may be well to say that most of the modern cotton mill plants use steam for heating direct from the boiler through pressure reducing valves, and not from any part of the exhaust of the engines.

\section{TABLE XVII.}

CoAL Reduchi to $\$ 3.00$ Per 2,000 Libs.

Combinen, Compound Condensing ano Smple Condensing.

\begin{tabular}{|c|c|c|c|c|c|}
\hline \multirow{2}{*}{$\begin{array}{c}\text { Number } \\
\text { of } \\
\text { Plant. }\end{array}$} & \multirow{2}{*}{$\begin{array}{c}\text { Hours } \\
\text { Run. }\end{array}$} & \multirow{2}{*}{$\begin{array}{c}\text { Average } \\
\text { Power. }\end{array}$} & \multicolumn{3}{|c|}{ E XPENSES. } \\
\hline & & & Operating. & Fixed. & Total. \\
\hline 19 & 10 & 2422. & $\$ .00460$ & $\$ .0<227$ & $\$ .00687$ \\
\hline 20 & 10 & 1909.7 &.$\infty 0527$ & .00224 & $.0075 \mathrm{I}$ \\
\hline Averages. & & $\ldots \ldots$ & $\$ .00494$ & $\$ .00225$ & $\$ .00719$ \\
\hline
\end{tabular}

Comparisons.

Of modern investigations of the cost of power, none stand higher than those of Dr. C. E. Emery in a paper before the American Instifute of Electrical. Engineers, March 21at, 1893, I have therefore thought it well to include here such parts of the tables as will afford a chance for comparison with the work of the writer and that of others. The investigation by Dr. Emery in this particular case was confined to the large unit of 500 net horse-power and its application must be limited to that amount as any departure will be found to vary the results. 
Style of

Key to Tabies XVIII, XIX, XX and XXI.

Engine.

A. Simple High Speed Non-Condensing.

B. Simple Low Speed Non-Condensing.

(.) Compound High Speed Non-Condensing.

D. Special Triple Componnd High Speed Non-Condensing.

E. Simple High Speed Condensing.

F. Simple Low Speed Condensing.

G. Compound High Speed Condensing.

H. Compound Low Speed Condensing.

I. Special Triple Compound High Speed Condensing.

J. Triple Compound, Low Speed Condensing.

K. Triple Compound, Low Speed Condensing.

L. Ditto, for probable maximum results.

As Dr. Emery's computations are made on net power and with coal at 2,240 pounds per ton, it has been necessary to reduce his figures to indicated horse-power and coal at 2,000 pounds per ton, the results being found in tables xvin and xix following. Where necessary to bring the items of expense under the same heads, changes have been made in his tables so that direct comparison of items may be made.

Table XviII shows itemized costs for 10 hour power per annum and in tables $\mathrm{xx}$ and $\mathrm{xxI}$ the totals have been reduced to cost

TABLE XVIII.

Emery's Tables Renuced to Indicated Horse-Power and Coal at $\$ 3.00$ Per 2,000 Lbs. 3,080 Hours Run.

\begin{tabular}{|c|c|c|c|c|c|c|c|c|}
\hline \multirow[b]{2}{*}{$\begin{array}{c}\text { Style } \\
\text { of } \\
\text { Engine. }\end{array}$} & \multicolumn{4}{|c|}{ OPERATING EXPENSE. } & \multicolumn{2}{|c|}{ FIXED CHARGES } & \multirow[b]{2}{*}{ Total. } & \multirow[b]{2}{*}{$\begin{array}{l}\text { Total } \\
\text { Cost. }\end{array}$} \\
\hline & Coal. & Labor. & $\begin{array}{c}\text { Repairs } \\
\text { and } \\
\text { Supplies. }\end{array}$ & 'Total. & $\begin{array}{c}\text { Insurance, } \\
\text { Taxes \& } \\
\text { Renewals }\end{array}$ & Interest. & & \\
\hline $\begin{array}{l}\mathrm{A} \\
\mathrm{B} \\
\mathrm{C} \\
\mathrm{D}\end{array}$ & $\begin{array}{r}\$ 19.70 \\
17.34 \\
15.54 \\
14.35\end{array}$ & $\begin{array}{r}\$ 4.4 \mathrm{r} \\
4.04 \\
3.84 \\
3.68\end{array}$ & $\begin{array}{r}\$ 2.73 \\
2.28 \\
2.73 \\
2.73\end{array}$ & $\begin{array}{r}\$ 26.84 \\
23.66 \\
22.11 \\
20.76\end{array}$ & $\begin{array}{r}\$ 2.72 \\
2.82 \\
2.52 \\
2.78\end{array}$ & $\begin{array}{r}\$ 5.90 \\
6.13 \\
5.49 \\
6.03\end{array}$ & $\begin{array}{r}\$ 8.62 \\
8.95 \\
8.01 \\
8.8 \mathrm{r}\end{array}$ & $\begin{array}{r}\$ 35.46 \\
32.6 \mathrm{x} \\
3^{0.12} \\
29.57\end{array}$ \\
\hline $\begin{array}{l}\mathrm{E} \\
\mathrm{F} \\
\mathrm{G} \\
\mathrm{H}\end{array}$ & $\begin{array}{l}1315 \\
1 \mathrm{Ir} .94 \\
11.95 \\
\text { 10 } 76\end{array}$ & $\begin{array}{l}3.5 \mathrm{I} \\
3.3 \mathrm{I} \\
3.35 \\
3.24\end{array}$ & $\begin{array}{l}2.73 \\
2.28 \\
2.73 \\
2.28\end{array}$ & $\begin{array}{l}19.39 \\
17.53 \\
18.03 \\
16.18\end{array}$ & $\begin{array}{l}2.32 \\
246 \\
2.39 \\
2.50\end{array}$ & $\begin{array}{l}5.04 \\
5.35 \\
5.16 \\
5.43\end{array}$ & $\begin{array}{l}7.36 \\
7.81 \\
7.57 \\
7.93\end{array}$ & $\begin{array}{l}26.75 \\
25.34 \\
25.60 \\
24.1 x\end{array}$ \\
\hline $\begin{array}{l}\mathrm{I} \\
\mathrm{J} \\
\mathrm{K} \\
\mathrm{L}\end{array}$ & $\begin{array}{r}1015 \\
9.56 \\
8.96 \\
7.50\end{array}$ & $\begin{array}{l}3.10 \\
\text { 2.98 } \\
2.90 \\
3.36\end{array}$ & $\begin{array}{l}2.73 \\
2.28 \\
2.28 \\
2.28\end{array}$ & $\begin{array}{l}15.98 \\
14.82 \\
14.14 \\
13.14\end{array}$ & $\begin{array}{l}2.53 \\
2.82 \\
3.02 \\
2.98\end{array}$ & $\begin{array}{l}5.49 \\
6.11 \\
6.56 \\
6.45\end{array}$ & $\begin{array}{l}8.02 \\
8.93 \\
9.58 \\
9.43\end{array}$ & $\begin{array}{l}24.00 \\
23.75 \\
23.72 \\
22.57\end{array}$ \\
\hline
\end{tabular}


per hour per horse-power in order to conform with the argument of the writer that the only correct safe statement is cost per hour and not per annum.

'TABLE XIX.

Emery's Tables Reduced to Indicated Horse-Power and Coal. AT $\$ 3.00$ PER 2,000 Lis. 7,300 Hours Run.

\begin{tabular}{|c|c|c|c|c|c|c|c|c|}
\hline \multirow{2}{*}{$\begin{array}{c}\text { Style } \\
\text { of } \\
\text { Engine. }\end{array}$} & \multicolumn{4}{|c|}{ OPERATING EXPENSE. } & \multicolumn{2}{|c|}{ FIXED CHARGES } & \multirow[b]{2}{*}{ Total. } & \multirow{2}{*}{$\begin{array}{l}\text { Total } \\
\text { Cost. }\end{array}$} \\
\hline & Coal. & Labor. & $\begin{array}{c}\text { Repairs } \\
\text { and } \\
\text { Supplies. }\end{array}$ & 'l'otal. & $\begin{array}{c}\text { Insurance: } \\
\text { Taxes \& } \\
\text { Renewals. }\end{array}$ & Interest. & & \\
\hline $\begin{array}{l}\mathrm{A} \\
\mathrm{B} \\
\mathrm{C} \\
\mathrm{D}\end{array}$ & $\begin{array}{r}\$ 44.70 \\
39.20 \\
35.20 \\
32.50\end{array}$ & $\begin{array}{r}\$ 10.45 \\
9.57 \\
9.11 \\
8.72\end{array}$ & $\begin{array}{r}\$ 6.47 \\
5.38 \\
6.47 \\
6.47\end{array}$ & $\begin{array}{r}\$ 61.62 \\
54.15 \\
50.78 \\
+7.69\end{array}$ & $\begin{array}{r}\$ 2.72 \\
2.83 \\
2.53 \\
2.78\end{array}$ & $\begin{array}{r}\$ 5.90 \\
6 . \mathrm{r}_{3} \\
5.49 \\
0.02\end{array}$ & $\begin{array}{r}\$ 8.62 \\
8.96 \\
8.02 \\
8.80\end{array}$ & $\begin{array}{r}\$ 70.24 \\
63.11 \\
58.80 \\
56.49\end{array}$ \\
\hline $\begin{array}{l}\mathbf{E} \\
\mathbf{F} \\
\mathbf{G} \\
\mathrm{H}\end{array}$ & $\begin{array}{l}29 \cdot 70 \\
27 \cdot 10 \\
27 \cdot 10 \\
24 \cdot 30\end{array}$ & $\begin{array}{l}8.34 \\
7.84 \\
7.93 \\
7.45\end{array}$ & $\begin{array}{l}6.47 \\
5.3^{8} \\
6.47 \\
5.3^{8}\end{array}$ & $\begin{array}{l}4451 \\
40 \cdot 3^{2} \\
41 \cdot 50 \\
37 \cdot 13\end{array}$ & $\begin{array}{l}2.32 \\
2.46 \\
2.39 \\
2.50\end{array}$ & $\begin{array}{r}\$ 5.04 \\
5.35 \\
5.17 \\
5.44\end{array}$ & $\begin{array}{l}7 \cdot 3^{6} \\
7 \cdot 81 \\
7 \cdot 56 \\
7 \cdot 94\end{array}$ & $\begin{array}{l}51.87 \\
48.13 \\
49.06 \\
45.07\end{array}$ \\
\hline $\begin{array}{l}\mathbf{I} \\
\mathbf{J} \\
\mathbf{L}\end{array}$ & $\begin{array}{l}22.90 \\
21.64 \\
20.30 \\
16.93\end{array}$ & $\begin{array}{l}7.35 \\
7.07 \\
6.85 \\
7.98\end{array}$ & $\begin{array}{l}6.47 \\
5 \cdot 3^{8} \\
5 \cdot 3^{8} \\
5 \cdot 3^{8}\end{array}$ & $\begin{array}{l}36.72 \\
34.09 \\
32.53 \\
30.29\end{array}$ & $\begin{array}{l}2.53 \\
2.81 \\
3.02 \\
2.98\end{array}$ & $\begin{array}{r}\$ 5.49 \\
6.14 \\
6.57 \\
6.44\end{array}$ & $\begin{array}{l}8.02 \\
8.95 \\
9.59 \\
9.42\end{array}$ & $\begin{array}{l}44 \cdot 74 \\
43 \cdot 04 \\
42.12 \\
39 \cdot 71\end{array}$ \\
\hline
\end{tabular}

TABLE XX.

Cost per Horse Power Hour, from Emery's Tables. 3,080 Hours Run.

\begin{tabular}{|c|c|c|c|}
\hline Style of Engine. & Operating Expenses. & Fixed Charges. & Total Cost. \\
\hline 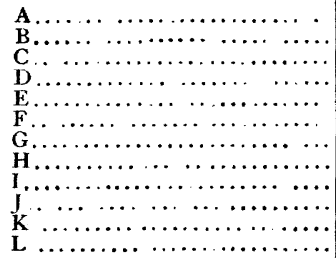 & $\begin{array}{r}\$ .00870 \\
.00769 \\
.00719 \\
.00675 \\
.00630 \\
.00570 \\
.00587 \\
.00526 \\
.00520 \\
.00482 \\
.00460 \\
.00428\end{array}$ & $\begin{array}{r}\$ .00280 \\
.00291 \\
.00261 \\
.00286 \\
.00239 \\
.00254 \\
.00246 \\
.00258 \\
.00261 \\
.00290 \\
.00311 \\
.00307\end{array}$ & $\begin{array}{r}\$ .01150 \\
.01060 \\
.00980 \\
.00961 \\
.00869 \\
.00824 \\
.00833 \\
.00784 \\
.00781 \\
.00772 \\
.00771 \\
.00735\end{array}$ \\
\hline
\end{tabular}

In a discussion of a paper before the American Society of Mechanical Engineers, Mr. Samuel Webber took occasion to state the itemized cost of steam power as developed in a Fall River yarn mill and the results are here given in tables xxIII and xxiv with coal reduced to $\$ 3.00$ per 2,000 pounds.

The totals will be found to agree fairly well with those from 


\section{TABLE XXI.}

Cont per Honse-Power, Holr, From Emery's Tables. 7,300 Houns Run.

\begin{tabular}{|c|c|c|c|}
\hline $\begin{array}{l}\text { Style of } \\
\text { Engine. }\end{array}$ & $\begin{array}{l}\text { Operating } \\
\text { Expenses. }\end{array}$ & $\begin{array}{c}\text { Fixed } \\
\text { Charges. }\end{array}$ & $\begin{array}{l}\text { Total } \\
\text { Cost. }\end{array}$ \\
\hline 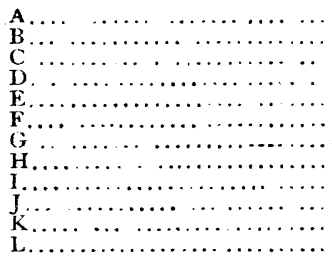 & $\begin{array}{l}.00845 \\
.00741 \\
.00695 \\
.00652 \\
.00610 \\
.00551 \\
.00568 \\
.00508 \\
.00502 \\
.00466 \\
.00445 \\
.00414\end{array}$ & $\begin{array}{l}.00122 \\
.00123 \\
.00112 \\
.00121 \\
.00101 \\
.00107 \\
.00103 \\
.00109 \\
.00110 \\
.00123 \\
.00131 \\
.00129\end{array}$ & $\begin{array}{l}.0067 \\
.00864 \\
.00805 \\
.00773 \\
.00711 \\
.00658 \\
.00671 \\
.00617 \\
.00612 \\
.00589 \\
.00576 \\
.00543\end{array}$ \\
\hline
\end{tabular}

Cost of Power, from Table in Enginfering Magazine, by Dr. Emery. Coal Reduced to \$3.00 per 2,000 Pounds. 3,080 Hours.

\begin{tabular}{|c|c|c|}
\hline & $\begin{array}{c}\text { Net } \\
\text { Horse-Fower. }\end{array}$ & $\begin{array}{c}\text { Cost per н. } P . \\
\text { per Hour. }\end{array}$ \\
\hline 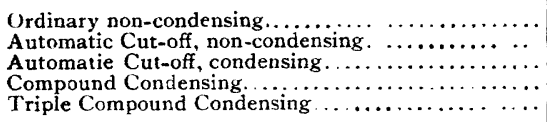 & $\begin{array}{r}10 \\
75 \\
150 \\
250 \\
500\end{array}$ & $\begin{array}{r}\$ .02570 \\
.01396 \\
.01060 \\
.00856 \\
.00727\end{array}$ \\
\hline
\end{tabular}

TABLE XXIII.

Cost of Power in a Fall River Yarn Mill. Samuei Webber. Coal Reduced to $\$ 3.00$ Per 2,000 Lis.

\begin{tabular}{|c|c|c|}
\hline & $\begin{array}{l}\text { Cost per } \text { H. }_{\text {r. }} \\
\text { per annum. }\end{array}$ & $\begin{array}{c}\text { Cost per H. P. } \\
\text { per hour. }\end{array}$ \\
\hline 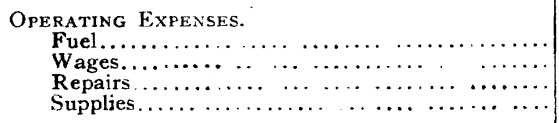 & $\begin{array}{r}\$ 9.20 \\
2.23 \\
1.57 \\
.31\end{array}$ & $\begin{array}{r}\$ .00299 \\
.00072 \\
.00051 \\
.00010\end{array}$ \\
\hline Total $\ldots \ldots \ldots \ldots \ldots \ldots \ldots \ldots \ldots$ & $\$ 13.31$ & $\$ .0043^{2}$ \\
\hline 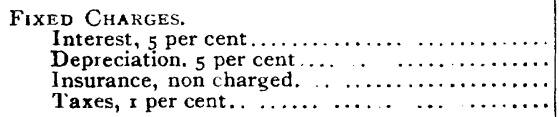 & $\begin{array}{r}\$ 3.15 \\
3.15 \\
\cdots \\
.32\end{array}$ & $\begin{array}{r}\$ .00102 \\
.00102 \\
.00010\end{array}$ \\
\hline Total $\ldots \quad \ldots \ldots \ldots \ldots \ldots \ldots \ldots \ldots$ & $\$ 6.62$ & $\$ .00214$ \\
\hline & $\$ 1993$ & $\$ .00646$ \\
\hline
\end{tabular}


similar plants, although no insurance has been taken into account; if $\$ .00007$ be added, the result will give a direct comparison with other estimates.

TABLE XXIV.

Cont of Power in Globe Yarn Mulis, No. 3. Fall. River.

Coat Reducen to $\$ 3.00$ per 2,000 Lbs. Samuer. Weber.

\begin{tabular}{|c|c|c|}
\hline & $\begin{array}{c}\text { Cost per } \mathrm{H.} \text { P. } \\
\text { per annum. }\end{array}$ & $\begin{array}{c}\text { Cost per H. P. } \\
\text { per hour. }\end{array}$ \\
\hline 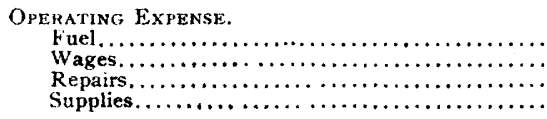 & $\begin{array}{r}\$ 1073 \\
2.89 \\
1.62 \\
.40\end{array}$ & $\begin{array}{r}\$ .00349 \\
.00094 \\
.00053 \\
.00013\end{array}$ \\
\hline Total $\ldots \ldots \ldots \ldots \ldots \ldots \ldots \ldots \ldots \ldots$ & $\$ 15.64$ & $\$ .00509$ \\
\hline 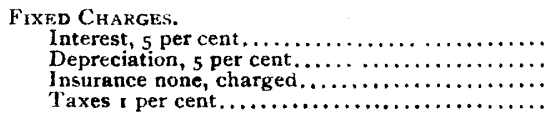 & $\begin{array}{r}\$ 3.23 \\
3.23 \\
\ldots . \\
.22\end{array}$ & $\begin{array}{r}\$ .00105 \\
.00105 \\
\ldots \ldots \ldots \\
\$ .00011\end{array}$ \\
\hline Total $\ldots \ldots \ldots \ldots \ldots \ldots \ldots \ldots \ldots$ & $\$ 6.78$ & $\$ .00221$ \\
\hline & $\$ 22.42$ & $\$ .00720$ \\
\hline
\end{tabular}

Table xxv, gives the result of a test made by Mr. R. S. Hale, expert for the Steam Users Association of Boston. Although

TABLE XXV.

Cost of Power in a Large Cotton Mill. R. S. Hale, Boston. Coal Reduced to $\$ 3.00$ Per 2,000 Lbs.

\begin{tabular}{|c|c|c|}
\hline & $\begin{array}{l}\text { Cost per H. }{ }^{\prime} \text {. } \\
\text { per annum. }\end{array}$ & $\begin{array}{l}\text { Cost per H. } P . \\
\text { per houtr. }\end{array}$ \\
\hline 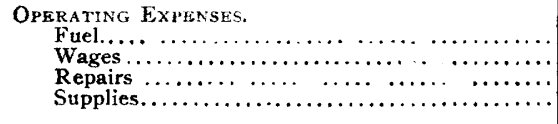 & $\begin{array}{r}\$ 6.92 \\
2.51 \\
.50 \\
.45\end{array}$ & $\begin{array}{r}.00233 \\
.00084 \\
.00017 \\
.00015\end{array}$ \\
\hline 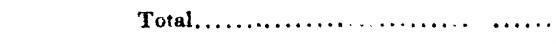 & $\$ 10.38$ & $\$ .00349$ \\
\hline 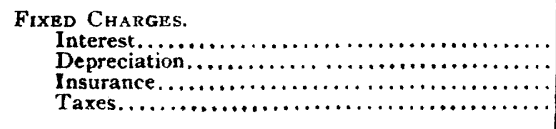 & $\begin{array}{r}\$ 2.90 \\
2.40 \\
.22 \\
.69\end{array}$ & $\begin{array}{r}\$ .00097 \\
.0008 \mathrm{I} \\
.00007 \\
.00023\end{array}$ \\
\hline Total............................... & $\$ 6.2 \mathrm{x}$ & $\$ .00208$ \\
\hline & $\$ 16.59$ & $\$ .00557$ \\
\hline
\end{tabular}


the actual result was somewhat higher than here shown, owing to a higher price of coal ; the result with coal reduced to the common standard is seen to be very low.

One of the plants instanced in a paper by Mr. May, before the American Society Mechanical Engineers, was the pumping engine of the North Point plant of the Milwaukee water works. As mentioned in a previous paragraph, it is not quite fair to compare water works plants with those used for other purposes, as the fixed charges are almost always high, and the labor necessary for the safety of fire service, etc., is higher than in ordinary plants. Still, as this plant was at the time the most economical steam machine in use, it is thought best to include it here. The net cost is seen to be well within limits of other estimates and is even lower than usual, owing probably to the fact of exceedingly high duty. If figures were obtainable, it would be very interesting to compare the results shown in table xxvi with similar costs on the Chestnut Hill pumping engine built by $\mathrm{Mr}$. Leavitt, which has since surpassed in economy the North Point engine.

TABIA XXVI.

Cost for Y tar 1892 of Running Pumping Exgines at North Point Plant of the Milwaukee Water Works.

Cont Renuced to $\$ 3.00$ per 2,000 Pounds.

\begin{tabular}{|c|c|c|c|}
\hline & $\begin{array}{l}\text { Cost for the Year. } \\
6,980 \text { Hours. }\end{array}$ & $\begin{array}{l}\text { Cost per } \mathbf{\text { H. }} \text {. } \\
\text { per annum. }\end{array}$ & $\begin{array}{l}\text { Cost per H. P. } \\
\text { per Hour. }\end{array}$ \\
\hline 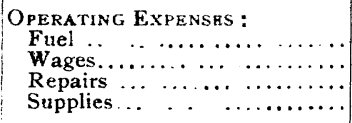 & $\begin{array}{r}\$ 9.266 .88 \\
10,680.00 \\
414.00 \\
754.00\end{array}$ & $\begin{array}{r}\$ 1654 \\
19.66 \\
.74 \\
\mathbf{I} .35\end{array}$ & $\begin{array}{l}\$ .00237 \\
.00273 \\
.00011 \\
.00019\end{array}$ \\
\hline $\begin{array}{l}\text { FIXED CHARGES : } \\
\text { Interest-5 per cent. on } \$ 72,500 . \\
\text { Depreciation }-4 \text { per cent. on } \\
\$ 72,500 \ldots \ldots \ldots \ldots\end{array}$ & $\begin{array}{r}\$ 21,114.88 \\
3,625.00 \\
2,90000\end{array}$ & $\begin{array}{r}37.69 \\
6.47 \\
5.17\end{array}$ & $\begin{array}{l}\$ .00540 \\
.00093 \\
.00074\end{array}$ \\
\hline & $\$ 6,525.00$ & $\$ 11.64$ & $\$ .00167$ \\
\hline Total Cost & $\$ 27,639.88$ & $\$ 49.33$ & $\$ .00707$ \\
\hline
\end{tabular}

In a paper read before the New York meeting of the American Society of Mechanical Engineers, and published in volume XI, of its Transactions, Mr. Chas T. Main of Lawrence, Mass. has 
TABI.E XXVII.

Cost of Steam Power per Annum.

From Tables of Chas. T. Main, Lawrence, Mass.

\begin{tabular}{|c|c|c|c|c|c|}
\hline 1,000 H. P. Engines. & $\begin{array}{c}\text { Coal } \$ 3.00 \\
\text { per } 2 \text { ooolbs. }\end{array}$ & Wages. & Repairs. & Supplies. & $\begin{array}{l}\text { Total } \\
\text { Operating. }\end{array}$ \\
\hline 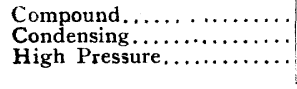 & $\begin{array}{l}\$ 8.28 \\
1182 \\
14.20\end{array}$ & $\begin{array}{r}\$ 3.48 \\
3.54 \\
3.85\end{array}$ & $\begin{array}{l}\$ 1.17 \\
\text { r.16 } \\
\text { r.17 }\end{array}$ & $\begin{array}{r}\$ 0.77 \\
.68 \\
.62\end{array}$ & $\begin{array}{r}\$ 1370 \\
17.20 \\
19.34\end{array}$ \\
\hline 1,000 н. P. Engines. & Interest. & Depreciation & Insurance & Taxes. & $\begin{array}{l}\text { Total } \\
\text { Fixed. }\end{array}$ \\
\hline 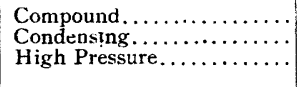 & $\begin{array}{r}\$ 2.92 \\
2.89 \\
2.93\end{array}$ & $\begin{array}{r}\$ 2.52 \\
2.56 \\
2.63\end{array}$ & $\begin{array}{r}\$ 0.26 \\
.26 \\
.27\end{array}$ & $\begin{array}{r}\$ 0.66 \\
.65 \\
.66\end{array}$ & $\begin{array}{r}\$ 6.36 \\
6.36 \\
6.49\end{array}$ \\
\hline \multicolumn{6}{|c|}{ Total Cost per h. P. per Annum. (308 Days.) } \\
\hline \multicolumn{2}{|c|}{ I,000 н. P. Engines. } & \multicolumn{2}{|c|}{ Operating. } & ixed. & Total. \\
\hline 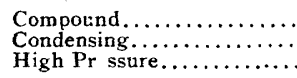 & ............ & $\begin{array}{r}\$ 13.7 \\
17.2 \\
19.8\end{array}$ & & $\begin{array}{l}6.36 \\
6.36 \\
6.49\end{array}$ & $\begin{array}{r}\$ 20.06 \\
23.58 \\
20.33\end{array}$ \\
\hline
\end{tabular}

TABLE XXVIII.

Cost of Steam Power per Hour per Horse-Power. 3,157 Hodrs. From Tables of Chas. T. Main, Lawrence, Mass.

\begin{tabular}{|c|c|c|c|c|c|}
\hline I,000 H. P. Engines. & $\begin{array}{c}\text { Coal @ } \$ 3.00 \\
\text { per 2,ocolbs. }\end{array}$ & Wages. & Repairs. & Supplies. & $\begin{array}{c}\text { Total } \\
\text { Operating. }\end{array}$ \\
\hline 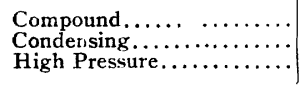 & $\begin{array}{r}\$ .00262 \\
.00375 \\
.00459\end{array}$ & $\begin{array}{r}\$ .00112 \\
.00112 \\
.00122\end{array}$ & $\begin{array}{r}\$ .00037 \\
.00037 \\
.00037\end{array}$ & $\begin{array}{r}\$ .00024 \\
.00022 \\
.00020\end{array}$ & $\begin{array}{r}\$ .00435 \\
00546 \\
.00629\end{array}$ \\
\hline I,000 н. P. Engines. & $\begin{array}{l}\text { Interest } \\
5 \text { per cent. }\end{array}$ & Depreciation & Insurance. & Taxes. & $\begin{array}{l}\text { Total } \\
\text { Fixed. }\end{array}$ \\
\hline 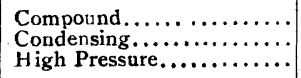 & $\begin{array}{r}\$ .00093 \\
.00092 \\
.00093\end{array}$ & $\begin{array}{r}\$ .00080 \\
.00031 \\
.00033\end{array}$ & $\begin{array}{r}\$ .00008 \\
.00008 \\
.00008\end{array}$ & $\begin{array}{r}\$ .00021 \\
.00021 \\
.00021\end{array}$ & $\begin{array}{r}\$ .00202 \\
.00202 \\
.00205\end{array}$ \\
\hline \multicolumn{6}{|c|}{ Total Cost Per Horse-Power per Hour. } \\
\hline \multicolumn{2}{|c|}{ I,, 00 H. P. Engines. } & \multicolumn{2}{|c|}{ Operating. } & Fixed. & Total. \\
\hline \multicolumn{2}{|c|}{ 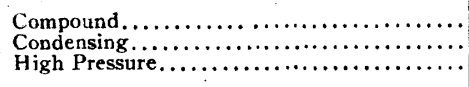 } & \multicolumn{2}{|c|}{$\begin{array}{r}\$ .00435 \\
.00546 \\
.00629\end{array}$} & $\begin{array}{r}\$ .00202 \\
.00202 \\
.00205\end{array}$ & $\begin{array}{l}\$ .00637 \\
.00748 \\
.00834\end{array}$ \\
\hline
\end{tabular}


developed to a most interesting degree, the cost of steam power for various costs of coal and where the exhaust from engines is used in varying quantities. He has divided the engines into three types or classes, i.e., compound, condensing and high pressure, which are the three types most used in his locality, which is largely a centre for the manufacture of textiles. He has also stated the costs for engines of 500, 1,000, 1,500 and 2,000 horse-power capacity for each type and the results are very interesting, but too elaborate to be included in full in this paper.

I have, however, in tables xxvi and xxvin assembled the unit costs for the various items, reducing the item of coal to the standard, for an engine of 1,000 horse-power of the three types, and with no exhaust steam used; in the first table, for the year, and in the seconi, per hour; the results will be found to agree fairly well with others.

\section{'TABLE XXIX.}

Comparison of Different Estmates. Large, Compolni) Condensing Engines.

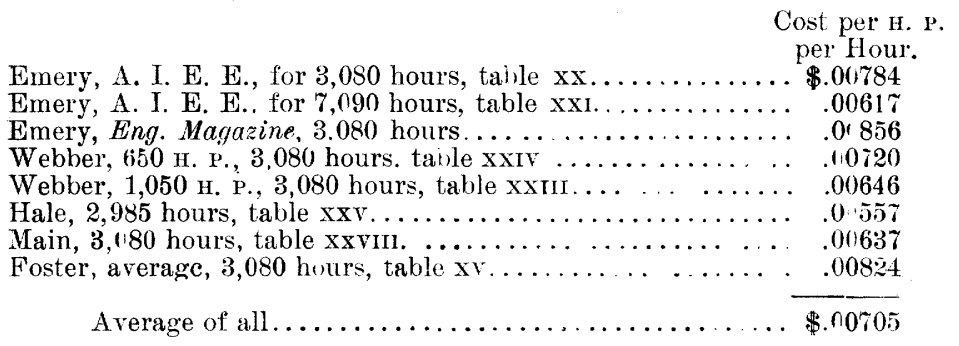

Conelusions.

The writer lias attempted in various ways, to group the foregoing tables for comparison with each other, but gave up the attempt as hopeless, with the exception of the class of large compound condensing engines used so generally in the large mills of the east; table XxIx shows the comparison of costs per hour as developed in the various tables in this class of engine, and although as previously stated by the writer, the average is hardly to be depended on for use in careful estimates, an average has been computed of the costs by different estimaters and is seen to be $\$ .00705$ per horse-power per hour. The especial point the writer desires to bring ont, is the widely varying costs here shown; take for instance Mr. Hale's of $\$ .00557$ as compared 
TABLE XXX.

Comparison of Cost of Power per Anncm. By Various Types of Engines. Coal at $\$ 3.00$ per 2,000 Lbs.

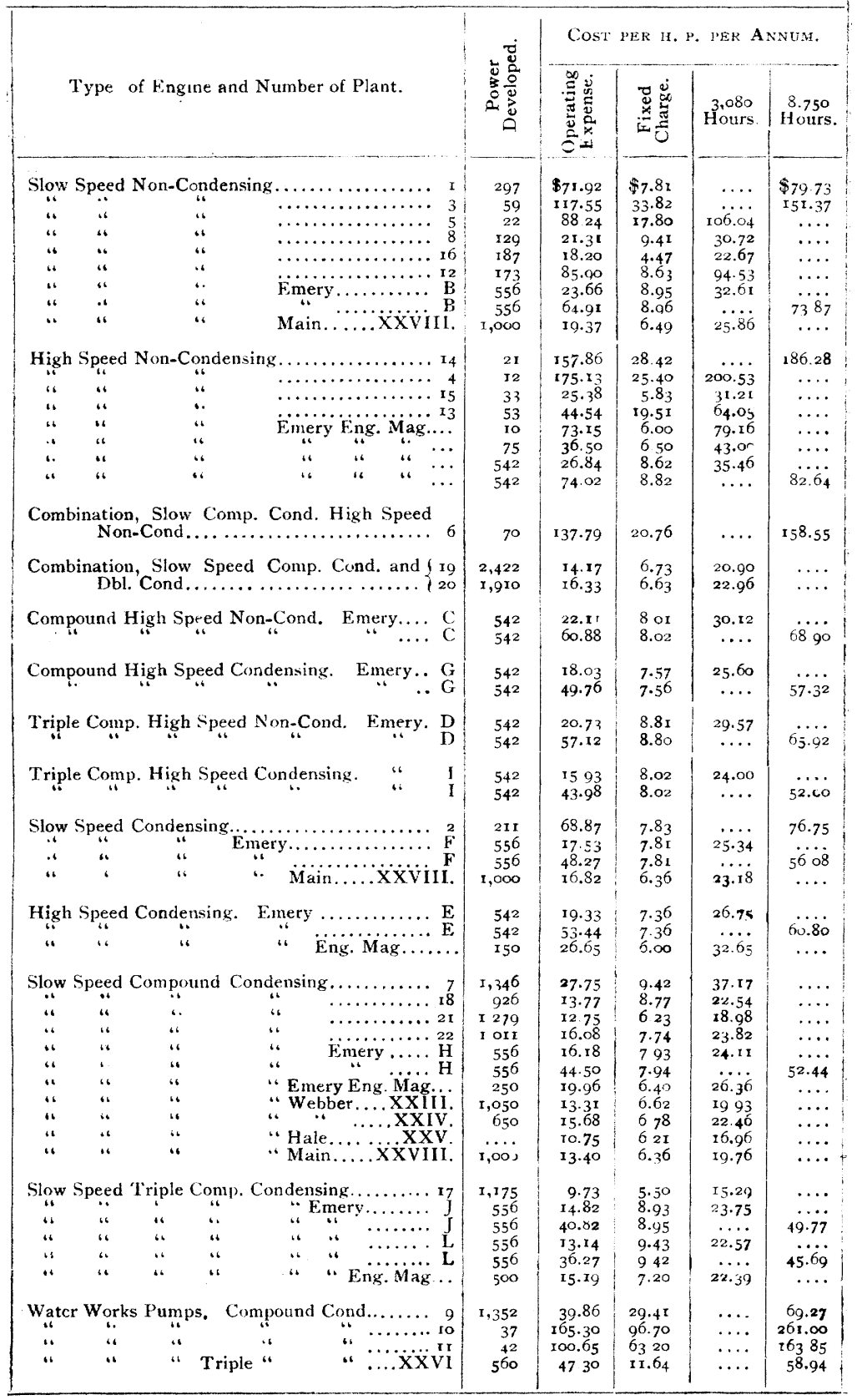




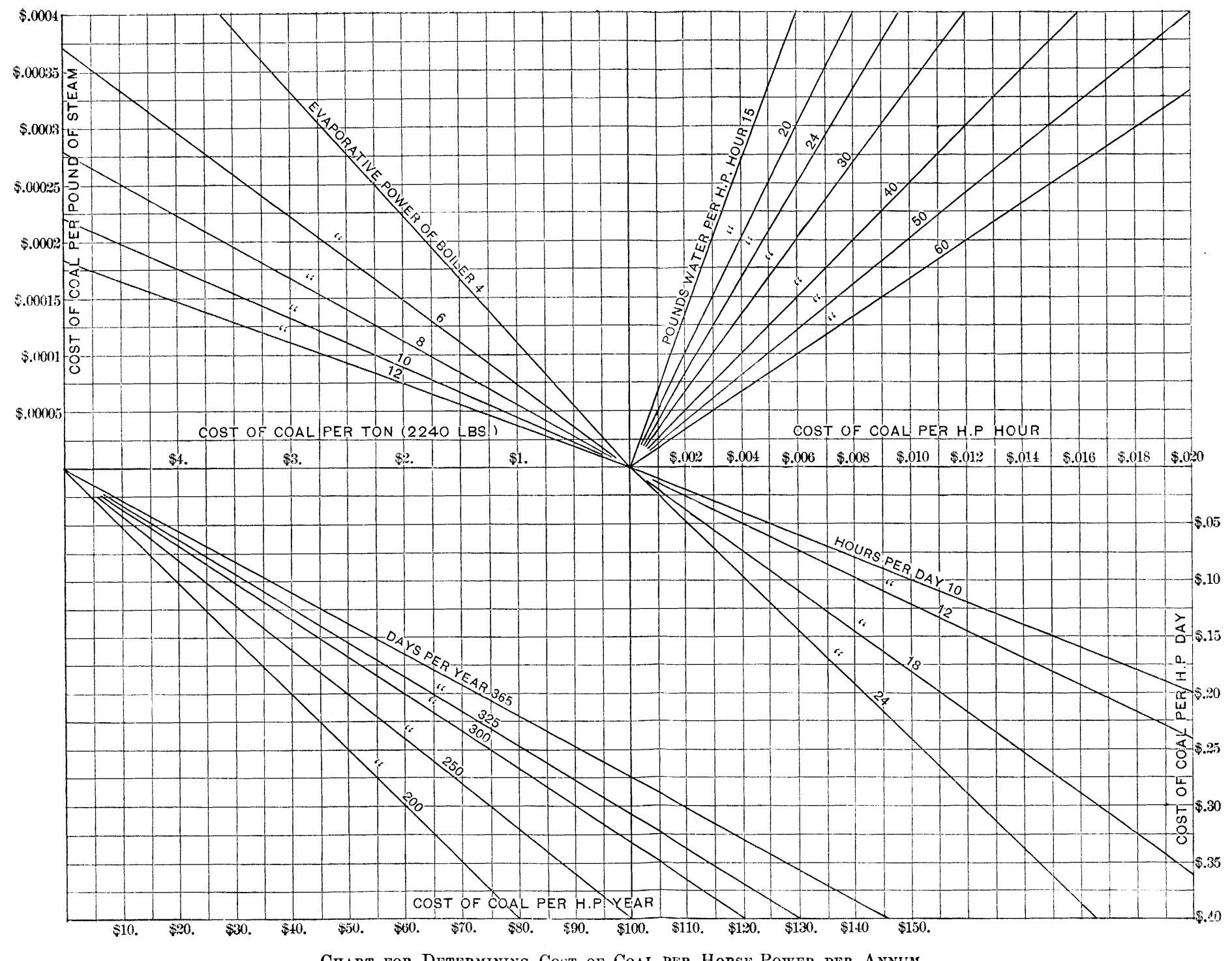

Chart for Determining Cost of Coal per Horse-Power per Annum.

[Included with this paper by kind permission of Mr. L. B. Stillwell, its designer.]

From this diagram the cost of coal per H. P. per annum is calculated as follows:

Beginning at "Cost of Coal per Ton" at left of centre of sheet, ascend vertical line to diagonal marked "Evaporative Power of Boilers," then follow horizontal line to the right to diagonal marked "Pounls Water per H. P. Hour," then follow vertical line downward to diagonal marked "Hours per Day" and from this point follow horizontal line to the left to point of intersection with diagonal marked "Days per Year." From this point of intersection follow vertical line downward to a scale at bottom of the diagram giving "Cost of Coal per H. P. Year." 
with Dr. Emery's of $\$ .00856$ or the writer's of $\$ .00824$, the two last are seen to exceed the first by about 50 per cent, a variation which the writer argues does not permit of stating average costs for general use. And finally, in order that the report may be of more practical value, the results have in table $\mathrm{xxx}$ been assembled and reduced to cost per horse-power per annum, for ten hours per day for 308 days, and for 24 hours per day for 365 days.

The first column gives the type of engines, with the number of the plant from the tables; next the amount of power developed, as showing the size of the plant; then operating and fixed expense; and in the last two columns, the total cost per annum for 3,080 hours and 8,760 hours.

This table allows a direct comparison of different plants, and different authorities. 